\title{
SOCIAL CONFLICT BETWEEN THE DRIVERS OF CONVENTIONAL WITH ONLINE TRANSPORTATION IN BANDUNG
}

Ardi Maulana Nugraha ${ }^{1^{*}}$, Munandar Sulaeman ${ }^{2}$, Wahyu Gunawan ${ }^{3}$

${ }^{1 *, 2,3}$ Department of Sociology, Universitas Padjadjaran, Bandung, Indonesia.

Email: ${ }^{*}$ ardimn13@gmail.com, ${ }^{2}$ mdr_sul@yahoo.com, ${ }^{3}$ wahyu.gunawan@unpad.ac.id

Article History: Received on $28^{\text {th }}$ January 2020, Revised on $15^{\text {th }}$ April 2020, Published on $15^{\text {th }}$ June 2020

\section{Abstract}

Purpose: Conflicts between conventional and online transport drivers have been disturbing and cause both physical and psychological casualties. The purpose of this research is to know the processes and factors that cause conflict.

Methodology: The research method is qualitative and descriptive. Transporters from Bandung city were accessed and interviewed. They were inquired about their views on the shift of conventional transportation to the online transportation system; later, these interview responses were analyzed to draw inferences.

Main Findings: The results of the research show that the process of conflict occurred from the transition of the use of conventional transportation services into online transportation in the city of Bandung. Furthermore, two forms of conflict occurred among transport drivers that are realistic and non-realistic conflicts. The causes of conflict are the seizure of economic resources (passengers), and the trigger factors are lack of communication and coordination among drivers, government delays in making regulations, and no solution to the problems that occur from the management of online transportation.

Implications/Applications: These results will be applicable for policy formation as well as removing conflicts between conventional transportation drivers and online transportation actors.

Originality/Value: Since: In Indonesia, online transportation has grown since 2015. However, some parties reject the presence of this online transportation, which causes a conflict. This study has thoroughly investigated the conflict between conventional transportation drivers and online transportation and highlighted the factors that cause these conflicts.

Keywords: Conventional Transport, Online Transport, Conflict, Drivers, People.

\section{INTRODUCTION}

Chronologically, tensions between conventional and online transportation actors began at the end of 2015. The first recorded case was the incident on October 3, 2015, namely a clash between an online motorcycle taxi and a base motorcycle taxi on the campus of the University of Indonesia (UI), Depok. Conflict continues and extends to other cities in Indonesia, one of which is the city of Bandung on October 22, 2015. Sutrisno (2015) explains that a base motorcycle taxi driver beat a battered motorcycle taxi driver Manisi near the Cibiru roundabout, Bandung, Java West. After the situation began to subside, four days later, on October 26, 2015, hundreds of base taxis joined in the Bandung Two Wheel Carriage Association (PAB) held a demonstration demanding that online transportation be eliminated in the city of Bandung. The government is trying to minimize conflict between the two parties by issuing Permenhub No.32 of 2016 on March 28, 2016, aiming to equalize conventional transportation and online-based transportation from various aspects. Nevertheless, this does not make the existing tension can be resolved concretely. The eruption occurred again when there was a demonstration conducted by taxi drivers who are members of the Bandung Taxi Driver Association (GPTB) on November 2, 2016.

The escalation of conflict is even higher when it is triggered by the government, which grants a road permit for online transportation drivers as stipulated in with Permenhub No. 32 of 2016. This regulation was responded to by conventional transportation large-scale demonstrations related to the rejection of the presence of online transportation in Bandung, which led to the destruction of private cars that were thought by the demonstrators to be online taxis on March 9, 2017. At the beginning of transportation based online, conflicts occur between ojekpangkalan and ojek online. However, this pattern then changed where conflicts now occur between urban transport, conventional motorcycle taxis, motorcycle taxis, and online taxis.

Of the several social conflicts that occur between conventional transportation drivers and online-based transportation (Pratiwi, 2017), there are several leading causes of conflict, one of which is the struggle for limited economic resources that have an impact on decreasing the income of conventional transportation drivers (De Dreu, 1997). If the government cannot handle this correctly, it can create an unhealthy business climate between entrepreneurs and drivers of traditional and onlinebased transportation. Conditions of conflict that do not lead to an agreement between the two parties peacefully, they then do not rule out the possibility of long-term impact on the social, cultural, and economic situation of the community, especially 
the drivers of conventional transportation and online transportation. Conflicts, in essence, often lead to disagreements based on a sense of disappointment that makes people experience dissatisfaction. In line with Coser's thinking in Pasha (2014):

Realistic conflict is a conflict that comes from disappointment with the unique demands that occur in the relationship and from the estimation of the possible benefits of the participants, which is shown on the object that is considered disappointing.

This horizontal conflict then raises the existence of solidarity within the group (in-group) and mutually tightens group ties with each other such as antipathy toward online-based transportation drivers. Certain groups feel the most righteous, prioritizing their group interests and unable to control emotions, and also become more aggressive because there is no concrete form of settlement. In line with Coser's, (1956) view that “conflicts that occur in people's lives can positively strengthen the social structure of society as long as the conflict can strengthen a group and be negatively functional if the conflict against the structure."

The role of the government itself becomes the regulator in making regulations relating to the transportation of online transportation roads. The revision of Permenhub No.32 of 2016 to Permenhub No. 26 of 2017 carried out is a form of government response in minimizing existing social conflicts between conventional and online transportation drivers. In line with Coser (in Johnson, 1990) that:

The safety valve is an institution of expression of dissatisfaction with a system or structure. Costa stated that through the rescue valve, hostility was inhibited so as not to turn against the original object.

This phenomenon is in line with researchers when trying to conduct a preliminary study among drivers of conventional transportation (city transportation) in the Ciroyom-earth beautiful route of the city of Bandung. According to the driver who was interviewed successfully by the researcher, the driver acknowledged that the existence of online-based transportation at the moment, was indirectly very detrimental to many parties, especially from the conventional transportation business actors. One example is in serving passengers where traditional transportation drivers are waiting for passengers. In contrast, in online-based transportation, the driver directly picks up passengers because they have been ordered through the Uber or Grab Car application so that passengers do not have to wait long. Besides, in terms of tariffs offered, online transportation also provides low prices (Alamsyah, 2018; Sudarnoto, 2015). That is why the driver feels very detrimental because online shipping has taken service users who been subscribed to conventional transit.

To get a comparison, the researchers then tried to interview drivers based on online transportation. The exciting thing is that the driver answered that the presence of online transportation services makes the use of services, especially the people of the city of Bandung, more comfortable to reach specific locations. Also, the price and service provide comfort to consumers. The real problem is in general transportation services that cannot accept a change. They feel they are been marginalized, even though, according to the driver, the online transportation service is not trying to eliminate conventional transportation services. They just do not like the existence of online transportation drivers and do not want to change their service standards to the community, so they try to limit access to online transportation by prohibiting taking passengers in certain places known as the red zone. Furthermore, the informant explained that the conflict had also occurred between transportation drivers in several areas, one of which was in Arcamanik, Bandung City on July 25, 2017, where the base motorcycle taxi was intimidating. By holding the mobile motorcycle taxi online and asking for a sum of 150,000 as fines for taking passengers in a prohibited area Furthermore.By the base motorcycle taxi.

Based on the description of the problem that the researcher described above, the researcher is interested in conducting a case study research highlighting the conflicts that arose when the conventional transport system was transitioned to an online transport system. Thus, the objective of this study are:

i) To investigate the impact of the online transportation system on conventional transportation business actors.

ii) To highlight the problems faced by conventional transport.

\section{LITERATURE REVIEW}

The modes of transportation that exist in the world develop along with the times and technology and follow the flow of globalization. The problems that arise related to the development of transportation in the world are also increasingly complex (Alamsyah, 2017; Rathod, 2016). The emergence of something new in society certainly creates dynamics that can lead to social problems. The emergence of application-based transportation has caused pros and cons in the community. Online transportation companies offer services that are safe, reliable, affordable, and with fairly efficient rates that can be obtained only by touching the application on a smartphone (Flores, 2017; Mohamed, 2016). On the one hand, online transportation is considered to make it easier for drivers and consumers. However, it gets a lot of criticism from conventional transportation drivers as it is considered as illegal transportation and seizes the livelihood of the drivers of conventional transportation services (Anwar, 2017; Kristo, 2017). 
In Indonesia, online transportation has grown since 2015 (Wijayanto, Sasami, Nugroho, \& Suharto, 2018). However, some parties reject the presence of this online transportation which causes a conflict. This is because the form of online transportation is online taxi bikes, considered to damage the conventional taxi bike market. Thus, it must be immediately handled (Pratiwi, 2017). Conventional transportation considers that the emergence of online transportation is detrimental because many consumers leave conventional transportation and switch to online transportation modes. The conflicts that occurred were caused by different tariffs and regulations between the online and the conventional transportation businesses in which online transportation companies did not do what conventional transportation companies did (Setyowati, 2017). This wave of problems regarding online transportation arises in many countries. One of the reasons is that the emergence of online transportation will damage the conventional transportation market until there is an unhealthy competition between the two. Hence, there is a need for strict regulations related to online transportation to improve safety, overcome congestion problems, and guarantee access for all customers (Cetin, 2017).

\section{RESEARCH METHODS}

The research method used descriptive and qualitative ones. This study is expected to provide flexibility in using a variety of collection techniques also, researchers can explore and study the development of conflicts that occur between conventional transportation drivers and online transportation in-depth and thoroughly.

To gather the data for this study, personal and professional resources were used and transport actors, including drivers and transport business owners, were interviewed. A series of interviews were conducted and several open-ended questions were put forth to dig out the information regarding their view-point on conventional vs. online transportation systems. The data obtained from interviews were documented and after the completion of the data collection stage, authors analysed the data thoroughly, identified themes and concerns and then drew the conclusion and formed inferences. No statistical tool is used for analysing the data.

\section{RESEARCH RESULTS AND DISCUSSION}

\section{Conflict Process}

\section{Differences in characteristics of drivers of conventional and online transportation}

The thing that causes online transportation tariffs to be more affordable is because of the cutting of licensing lines that should be done by online transportation parties like conventional transportation in general.

The presence of online transportation in the city of Bandung is a very real innovation by bringing in lower tariffs and driving comfort but, on the other hand, the public does not know that until now the companies, both Grab, Gojek and Uber, have not contributed to the region due to the absence of tax payments to the areas and also Grab, Gojek and Uber companies do not provide clarity in terms of company licenses. This is in line with Mr. KR who explained that the online transportation company does not want to be called an online transportation company but as a provider of transportation service applications, but also, on the one hand, the transportation service company that makes it unclear to the government in deciding the type of online transportation company today.

Also, to date, especially in the city of Bandung, there has not been any online transportation that has received official permission from the central government since the revocation of 14 articles in Permenhub 26 of 2017. Previously, the rules in online transportation road permits have been contained in Permenhub 32 of 2016, but because of conventional transportation parties who feel the laws of the road permit do not give justice to the transportation drivers which led to massive demonstrations in several areas, one of which in the city of Bandung finally changed to Permenhub 26 in 2017.

Public and private vehicles are included in the current transportation category. KBBI (2012) explains that classical is "based on general conventions (agreements) (such as customs, habits, custom)." So public vehicles such as city transportation, buses, trains and so on are included in the type of conventional transportation because cars are used based on an agreement utilizing a road permit from the government.

In general, conventional vehicles operate according to rules set by the government. In terms of transportation, the features of traditional transport are official because several attributes must be possessed by each vehicle, such as terminals, pools, or vehicle bases, which are not in the name of the person, proper vehicle test (KIR), and special driving license (SIM). For conventional transportation drivers and license plates as vehicle identity. In contrast to Mr. KR, Mr. DI revealed that he agreed with the presence of online transportation in the city of Bandung. This is because in addition to providing benefits to the city of Bandung as a user of public transportation services. Besides, the emergence of online transportation in the city of Bandung provides new jobs that also have an impact on helping the community economy. Those who work as online motorcycle taxi drivers can bring money of 100 to 200 thousand per day. As for online taxis, the informant explained that he could bring 300 to 500 thousand in one day. 
The need for a substantial model of transportation accompanied by high mobility and the times has become an essential part of human life. Integrated, fast, safe, convenient mode of transportation with a relatively low cost is the hope of the community. But in reality, the need for transportation modes is not accompanied by the provision or procurement of adequate and adequate transportation modes by the government. Munawar (2011) argues that in addition to a proper city road network system for the movement of private transport, and the efficient city must also be able to provide a mass transportation system that is efficiently and reliably capable of transporting people in large numbers and in a relatively short time.

Online transportation is alternative transportation that offers the development of transformation from the old system into a system that is entirely different but very suitable for the needs of people who have high mobility, especially in big cities like Bandung. Nowadays, online transportation offers driving comfort with affordable rates and is quite competitive compared to other official taxis so that online shipping is experiencing rapid growth and growth in the city of Bandung. Wijaya (2016) explained that the features of online road transportation such as Uber, Grab, and Gojek were the synthesis of conventional transportation methods and electronic transaction methods. The features of online road transportation can be said to combine the elements of traffic regulated by Law No.22 of 2009 and the implementing regulations with aspects of electronic transactions regulated in Law No.11 of 2008 concerning information and electronic transactions.

Application-based online transportation on passenger smartphones makes the booking path very effective and efficient. As stated by Mcluhan in (Nurudin, 2012) that we form equipment to inform and finally the equipment to communicate that we use ultimately shapes or influences our lives practically and instantly.

As an online transportation or data network, online transportation does not only function as a user transportation service but also functions in shipping goods, food, and so on. Kamaluddin (2003) argues that transportation means transporting or carrying (something) to another side or from another place. This means that transportation is a service provided, to help people and goods to be carried from one place to another.

\section{Consumer service differences}

Services between conventional transportation and online transportation are also very different. Starting from the price rates that can indeed reach all sections of society as well as positively influence the attitude of drivers who are friendly to consumers. Besides, in online transportation, there is a consumer complaint service where when there is a service that does not charge from the driver, the consumer can directly contact the customer service to be followed up immediately. In contrast to conventional transportation, where if there are services that are felt to be uncomfortable from drivers both urban transportation and taxis, consumers cannot express their complaints.

The use of online transportation services results from very unsatisfactory services from conventional transportation drivers. Such as city transportation which is considered inflexible and inefficient in transporting passengers. Also, the behaviour of the drivers who are not polite in talking and then driving recklessly coupled with if you want to use city transportation must wait in advance, unlike online transportation that picks up directly from the consumer's home and deliver to the destination without having to change transportation with the route which has been set. In addition to city transportation, conventional taxis are also considered less than the online taxis, which explained that in terms of prices which are relatively more expensive and vary from one taxi to another.

The community does not only felt the positive impact of the presence of online transportation but also thought the online transportation, both motorcycle taxi and taxi, can help the family's economic income and provide new jobs to the broader community. Adisasmita (2014) explained that transportation services have a vital role not only to smooth the flow of goods and human mobility, but transportation services also help to achieve the optimal allocation of economic resources, which means that production activities are carried out effectively and efficiently. Job opportunities and community incomes have increased so that inequality between regions be reduced as low as possible.

The emergence of a transition in the community in the use of public transportation services to use online transportation is also due to the saturation of the community towards the services of conventional transportation drivers. Inlinewith $\underline{\text { Salim }}$ (2006) i.e., the population of the movement of private vehicles is so huge in urban areas due to the pattern of public transportation that is still traditional and cause numerous social costs such as wastage of fuel, time, depressing vehicles that are too fast, traffic accidents, prolonged stress, increased air pollution and noise.

Online transportation is becoming an evolution in the current transportation industry where people are increasingly facilitated in accessing mobility, especially in big cities like Bandung. The purpose of online transportation itself is to provide comfort and convenience to the public, and relatively affordable price. Warpani (2002) argues that for transport companies (operators) that produce transportation services to the public transport users (users), then in principle, there are four functions in transportation service products namely, safe, orderly, and organized (regularity), comfortable (comfort), and economical. 
Online transportation provides relatively short travel distances compared to conventional transportation in general. Also, friendly service and provide a sense of security, as well as affordable prices, make the city of Bandung switch to transportation that uses information technology-based applications at this time.

\section{Competition between conventional and online transportation drivers}

Conventional taxi drivers who have been operating for 20 to 30 years feel that the presence of online transportation in the city of Bandung is very detrimental to taxi drivers in the city of Bandung. Before the online transportation, they could bring home 100-150 thousand money per day if it was busy, whereas if the conditions were quiet, their passengers said that they could bring a minimum of 100,000 per day. But when online transportation is present in the city of Bandung and picking up passengers who have been subscribed to taxi drivers, even for 100 thousand, it is tough to get, in contrast, the company's demands for taxi drivers must give 150-175 thousand per day depending on the taxi company in question. Rarely can they bring home the money they have earned?

Because of the decline in income felt by conventional transportation drivers, competition arises which results in conflicts that occur at several motorcycle taxis as well as taxi bases and city transportation in Bandung. Existing competition between conventional and online transportation drivers in the city of Bandung occurs in the form of threat intimidation, which is the prohibition of operating motorbike taxis and online taxis in several areas in the city of Bandung. It can be seen that some areas in the city of Bandung are prohibited from taking cargo or individual passengers by base taxi.

The pool ojek drivers intending to have a motorcycle taxi between conventional and online can understand each other by not taking cargo or passengers who are in their area. If they (ojek online) take cargo from outside the base ojek area and will deliver to the pangkalanojek area it should drop off at ojekpangkalan beforehand so that it can be delivered again by ojekpangkalan to carry passengers to the consumer's house which is mostly sharing in sustenance.

However, in reality, the online motorcycle taxi drivers have no respect for the base motorcycle taxi so that competition arises until a prolonged conflict. It is clear here that the ojekpangkalan feels disadvantaged because the online ojek takes passengers who have long been subscribed to the ojegpangkalan. Every day the online motorcycle taxis take passengers by not using attributes. Since there are online motorcycle taxis and taxis, looking for sustenance is not calm and comfortable because the workload is increasing by monitoring the absence of online motorcycle taxi and taxis that take passengers in their area. On the other hand, the drivers of online transportation are uneasy because of the assumption of conventional transportation that online transportation steals passengers who have long been subscribed to them and is forced to pick up passengers in a clandestine way if they are in the motorcycle taxi base.

As for conventional taxi drivers and city transportation, the area of operation of both taxis and online taxis cannot be limited because their area of operation is quite extensive unlike base taxis; where the area is based on the area of each of the base's motorcycle taxis and is not formally determined by the route precisely, like city transportation. Competition occurs because of the struggle for limited economic resources. Porter (2008) explained that competition is a dynamic process carried out between companies or sellers to win race and expansion. The applied strategic practice, which is to reduce prices, advertise goods/services (broadcast), investment in R\&D, and other strategies.

As a result of the inconvenience that is present in service users, finally, there is a form of protest action on conventional transportation in the city of Bandung to be able to choose free public transportation and do not want conflicts between transportation drivers. Conventional transportation drivers cannot prohibit the presence of online transportation in the city of Bandung because technological developments will always be present and cannot be stopped. Also, competition could potentially lead to conflict between the two parties, they feel pressured when going to use online transportation services. Technology has changed people's shopping behaviour into online shopping so that it can reduce the income of conventional transportation drivers and give birth to unemployment. Saebani (2016) argues that technological advancements that are equipped with increasingly sophisticated interactive media such as internet cell phones and other electronic media if management is not appropriate will harm people who do not have the mental readiness to accept the advancement of existing technology. The large number of people who use online transportation services makes conventional transportation drivers experience a significant decrease in income to cause competition that leads to conflict between transportation drivers. As stated by Damsar (2009), who explains that the development of economic problems goes hand in hand with the development of human growth itself with the technological, knowledge possessed.

In the era of the technological industrial revolution, diffusion occurred in various technological advances. Innovation moves fast and everything is connected. Alvin L. Bertrand in (Stompzka, 2010) explains that one of the channels of the process of social change is diffusion i.e., the process of spreading aesthetic elements (ideas, beliefs, cultural results, etc.) from one individual to another individual, from one group to another, or from one community to another.

Technology is slowly beginning to change the pattern of life and thought patterns of people in the city of Bandung, which is easily influenced by new things. Technological advances have caused many significant changes in the lives of humankind, 
including innovations in the field of transportation services that have become online-based where the public feels these advances.

\section{The conflict between driver transportation}

Chronological conflicts that occur are in several ojek bases such as Al-Islam ojek, Gedebage, PasirImpun, and Nibiru. The battle continued, on the indirect attack from the online driver represented by one of the online transportation communities in the city of Bandung, LaskarSasaji (SarasaSajiwa) on September 2, 2017. This indirect attack was called the "Abdurahman Greening movement", where they request that along the Pajajaran road to HuseinSastranegara airport be freed from the red zone of the pangkalanojek. Suyanto and Narwoko (2007) explained that conflict is a social process that takes place-involving people or groups who oppose each other with the threat of violence.

Conflicts that occur, can be mediated by the local police which in the end the motorcycle taxi drivers still refuse to green along the Pajajaran road to HuseinSastranegara airport because of their strategic location and if they are released to the online motorcycle taxi drivers, their profession as motorcycle taxi drivers bases will also be threatened which will result in a significant decrease in income. Kovach in (Rohmah, 2002) added that mediation is a negotiation facilitated by a neutral third party to find a mutually satisfying resolution.

Besides, to external conflicts between pangkalanojeks and online ojeks, there are also internal conflicts within the Citepus base ojek where there are several members who have joined to become online ojeks and there has been an action from the head of the pangkalan base ojek itself by removing the member dishonourably and route money (the way ) that has not been given cannot be taken back also the individual base motorcycle taxi membership can no longer be activated in the area of any base motorcycle taxi. Coser (1956) explains that two conflicts occur in society, namely, external conflict (outgroup) and internal conflict (in-group). Internal conflicts are conflicts that occur within the group or the community itself. For example, contradictions due to problems within the community itself to the point of causing conflict and hostility between members of the community. This internal conflict causes non-realistic conflicts in some of the motorcycle taxis. Some base ojegs want to join only to get pressure from the head of the oasis in the area of each base ojek not to be part of an online ojek such as the ones at PasirImpun, Jatihandap and Gedebageojek bases. Fisher and Kartikasari (2001) state that one form of social conflict is latent conflict in which it is hidden and needs to be raised to the surface so that it can be dealt with effectively.

The conflict continued between conventional taxi drivers and online taxis precisely in the PrimajasaCaringin Pool on September 12, 2017. The conflict arose from the attitude of disrespect for online taxi drivers who took charge or passengers of PrimajasaCaringin Pool so that one of the drivers did a hard watering conventional taxi to online taxi car units.

On the other hand, the conflict continued at Cibiru Manisi on September 16, 2017, where there were quarrels between ojek and online motorcycle taxis due to misunderstanding and destruction of online taxis and beating of the drivers. Wahyuni(2007) that conflict in a negative sense is often associated with violence, destruction, uncontrolled emotions, rahrah, strikes, and demonstrations. While the conflict in a positive sense is often referred to as fair competition where the competing parties consciously achieve a goal. Anwar (2013) also explained that conflict can also be interpreted as a process in which individuals or groups try to fulfill their objectives by challenging opponents accompanied by threats and violence.

The conflict occurred again on October 4, 2017, where there was a beating and destruction of an online taxi car unit from a city transportation driver with the Sarijadi-Ciroyom route. In some cases, conflicts that occur between conventional and online transportation drivers are cases of realistic conflict, where this conflict stems from the existence of rational demands by the warring parties. The rational demands that are contested are in real form, namely the users of transportation services in the city of Bandung and the driver's operating area. Furthermore, this realistic conflict gives birth to emotions to act rationally in defence of its purpose. As expressed by Coser, (1956) that realistic conflict is a conflict that occurs in a society/community group that comes from the existence of rational demands and there are forms of real objects contested.

As a result of government uncertainty and delays in responding to conflicts, management is also unable to provide solutions to the problems that occur (Darlington, Feeney \&Rixon, 2004), online transportation drivers in Bandung have the initiative to create an association to become a bridge between online and conventional transportation drivers in Bandung cities such as the Bandung Raya Driver Association (HDBR), the Bandung Online Driver Association (ADOB), BarayaBatim Bikers (BBB), and Brave Parahyangan Rider (BPR) are some of the largest online transportation drivers communities in the city of Bandung.

The online transportation communities in the city of Bandung aim to build solidarity by bringing together drivers whose original individuals or single fighter have the power to coordinate and communicate with conventional transportation and function to deal with conflicts. This is because the average case of conflict that occurs due to drivers who do not follow a community which results in a lack of information about the red zone area as well as communication with conventional transportation. Conflict functionalism according to Coser, (1956) is that conflicts with other groups can produce solidarity within groups and tighten the ties of groups with loose structures (people who experience disintegration/conflict with other 
groups/communities can improve integration cohesion). Furthermore, conflict can create social cohesion through other group alliances (establishing cooperation with other groups to weaken one of the conflicting group relationships) and conflict can also cause isolated community members to play an active role (Cherry \&Adelakun, 2012; Haris, 2014; Rubin, Pruitt \& Kim, (1994). Just like online transportation drivers, in responding to conflicts, conventional transportation drivers try to build solidarity among conventional transportation drivers. Starting from the pangkalanojek, the PangkalanOjek Association (POP) that was previously the Arda Bandung Association (PAB). This POP organization helps members of the base motorcycle taxi when conflicts occur with the online transportation driver.

Furthermore, for urban transport drivers themselves formed WAAT-JB (Wada Alliance of West Java Transportation Aspirations). WHAT organization serves to convey the aspirations of both complaints and input in conflicts that occur between transportation drivers to interested parties such as the Department of Transportation of the cities of Bandung and West Java as well as the government relating to existing problems. As explained by Coser (1956) which provides the view that, conflicts that occur in people's lives can positively strengthen the social fabric of society insofar as the conflict can strengthen the group and be negatively functional if the conflict against the structure. Positive conflict can ease tensions within what happens in a group by enhancing balance and wholeness. Conflict theory assumes that (1) Conflict tends to increase social adjustment (adaptation) and maintain group boundaries, (2) Conflict arises when there is access from the claimant to get rewards according to his work, (3) The tighter the stratification system, the fewer institutions safety valve, (4) The lower the institutionalization of tolerant institutional conflict, the easier it is to increase group participation higher. (5) The more prolonged and more intense the group struggle, the more the potential for social conflict.

Conflicts can only be minimized among transportation drivers after the issuance of Permenhub 26 of 2017 revised to Permenhub 108 of 2017. The purpose of the Permenhub revision itself is to prevent the escalation of the conflict that is higher among transportation drivers. Coser explained (Johnson, 1990) about safety valves (safety valves) where the rescue valve is one of the unique mechanisms that can be used to defend groups from possible social conflict. The rescue valve allows the spill of hostility to be channeled without destroying the entire structure. Conflict helps "clear the atmosphere" ingroups that are in turmoil. Coser (1956) is of the view that the rescue valve serves as a way out which alleviates hostility without which relations between opposing parties will sharpen. The rescue valve is an institution of expression of dissatisfaction with a system or structure.

Ministry of Transportation Regulation 108 of 2017 itself is only to become special four-wheeled transportation while for online motorcycle taxis, there is no clear legal umbrella because two-wheeled transportation is not included in the qualifications of public transportation. At this time there was a demonstration by the driver, especially an online motorcycle taxi, which demanded the government to immediately revise Law No.22 of 2009 to include prayer wheel transportation into public vehicles.

\section{Factors Causing Conflict}

In general, conflicts that occur between transportation drivers originate from economic factors where the transition from the use of conventional transportation services to online transportation in the city of Bandung, resulting in a very significant decrease in income. Conventional transport drivers who feel threatened by their profession either as a base motorcycle taxi, city transportation driver, and traditional taxi driver, causing conflicts between groups. Ueberschall in Maftuh(2008) states that the causes of conflict include unjust social order (differences in position or social status), economic dissatisfaction, political dissatisfaction, and the strengths and weaknesses of social institutions.

Besides, there have been no concrete resolution efforts between the two parties and the motorcycle itself tends to avoid conflict. Coser (1956) also argues that realistic conflicts have concrete or material sources, such as the struggle for economic or regional resources.

The presence of online transportation is slowly making conventional transportation to be abandoned. This is considered by the driver to feel disadvantaged by online transportation. Moreover, since the advent of online transportation in Indonesia, especially in Bandung, this service has not had a clear legal umbrella.

Online transportation uses private cars (black plate cars) as public transport, does not have official status as a legal entity, and does not have official licenses to operate like other public transportation, and differences in service systems provide social jealousy among transportation drivers. Saebani (2016) explained that horizontal and vertical social conflicts are rooted in several structural factors, social jealousy due to social and economic inequality in various groups of society.

The triggering factors in the conflict itself are the lack of communication and coordination in advance from the online transportation to conventional transportation drivers, especially motorcycle taxi drivers, city transportation drivers, and conventional taxis. Communication and coordination here is mutual respect and respect among fellow motorcycle taxi drivers both online and base or conventional taxis and online taxis so as not to take passengers to each other within the designated area. 


\section{CONCLUSION}

Based on the results of the study, there are two forms of conflict that occur between transportation drivers, namely realistic conflicts and non-realistic conflicts. Conflict functionality is demonstrated by the presence of an organization or organization created in building solidarity among transportation drivers. While the rescue valve is shown by the presence of the Ministry of Transportation issuing the Pemenhub 32 in 2016 and 26 in 2017 also 108 in 2017.

The cause of conflicts that occur among transportation drivers is in the form of a struggle for limited economic resources (passengers). The triggering factors include lack of communication and coordination between drivers, government delays in making clear regulations on the rules of online transportation road licensing, government uncertainty in handling conflicts that occur, and the absence of action or solutions to problems that occur from the management of online transportation.

\section{LIMITATION AND STUDY FORWARD}

There are potential limitations of this study that must not be overlooked. First of all, the sample chosen for this study is relatively small which might not be a representative of the whole population. Because of the scarcity of time and resources gathering data from maximum transporters was not feasible thus, future studies with a large sample size must be conducted to get a deeper insight into the conflict between conventional and online transportation drivers. Moreover, as highlighted, two types of conflicts arise in response to a transition of conventional transport to the online transport system, future researchers must investigate that how do conventional transport actors cope with these conflicts and what strategies are they using for adapting to the situation. Similarly, this study only gathered viewpoints of drivers in the city of Bandung, whether consumers/passengers also get affected by such situations or what are their preferences for transportation systems are some questions that ought to be answered in the future. Such studies will help policymakers and governments in handling ongoing conflicts more effectively.

\section{ACKNOWLEDGMENT}

This research is the original work of the authors and no financial support is received from any actor for conducting this research. The authors would like to thank the transport business actors for providing valuable feedback for this study.

\section{AUTHORS CONTRIBUTION}

Ardi Maulana Nugraha contributes significantly to designing the instrument, and data collection. Munandar Sulaeman provides data analysis and contributes to the additional literature review and performs proof-reads the final manuscript. Wahyu Gunawan helped in the conception and analysis of the quality of the manuscript.

\section{REFERENCES}

1. Adisasmita.(2014). Transportation development management. Yogyakarta, Indonesia: Grahallmu.

2. Alamsyah, A., \&Rachmadiansyah, I. (2018, March).Mapping online transportation service quality and multiclass classification problem-solving priorities. In Journal of Physics: Conference Series (Vol. 971, No. 1, p. 012021). IOP Publishing. https://doi.org/10.1088/1742-6596/971/1/012021

3. Anwar.(2013). Sociology for universities. Bandung, Indonesia: PT. RefikaAditama.

4. Cherry, C. R., \&Adelakun, A. A. (2012). Truck driver perceptions and preferences: Congestion and conflict, managed lanes, and tolls. Transport Policy, 24, 1-9. https://doi.org/10.1016/j.tranpol.2012.07.012

5. Coser. (1956). The function of social conflict. New York, NY: The Free Press.

6. Damsar.(2009). Economic sociology. Jakarta, Indonesia: PT. Raja GrafindoPersada.

7. Darlington, Y., Feeney, J. A., \&Rixon, K. (2004). Complexity, conflict and uncertainty: Issues in collaboration between child protection and mental health services. Children and Youth Services Review, 26(12), 1175-1192. https://doi.org/10.1016/j.childyouth.2004.08.009

8. De Dreu, C. K. (1997). Productive conflict: The importance of conflict management and conflict issue. Using conflict in organizations, 9-22. https://doi.org/10.4135/9781446217016.n2

9. Fisher, S. \&Kartikasari, S. N. (2001).Managing conflict: skills \& strategies for action.British Council Responding to Conflict (RTC), Jakarta, Indonesia.

10. Haris.(2014). Sociology of mass communication. Bandung, Indonesia: PT. RemajaRosdakarya.

11. Johnson, D. P. (1990).Theories of classical and modern sociology( Vol. I \&II). Jakarta, Indonesia: Gramedia.

12. Kamaluddin.(2003). Transportation economics characteristics, theory and policy. Jakarta, Indonesia: Ghalia Indonesia.

13. KBBI.(2012). Conventional.Retrieved from http://kbbi.web.id/konvensional.

14. Maftuh.(2008). Pending dispute resolution. Bandung, Indonesia: CV Yasinod Multi Aspek.

15. Munawar.(2011). Fundamentals of transportation engineering. Yogyakarta, Indonesia: Beta Offset. 
16. Nurudin.(2012). New social media and the emergence of the communication process revolution. Yogyakarta, Indonesia: Buku Literal.

17. Pasha, G. (2014).Theories of modern sociology. Bandung, Indonesia: Rizqi Press.

18. Porter. (2008). Competitive strategy.Tanggerang, Indonesia: Karisma Publishing Group.

19. Pratiwi, A. (2017). Social Conflicts between Ojek Online Drivers with ThePangkalanOjekRailers in Curug, KelurahanBojongsari, Depok City. Meaning: Journal of Communication, Language and Culture Studies, 2 (1), 1-14.

20. Rohmah.(2002). Agrarian conflict resolution paradigm. Yogyakarta, Indonesia: WaliSongo Press.

21. Rubin, J. Z., Pruitt, D. G., \& Kim, S. H. (1994). Social conflict: Escalation, stalemate, and settlement. Mcgraw-Hill Book Company.

22. Saebani.(2016). Perspective of social change. Bandung, Indonesia: CV PustakaSetia.

23. Salim.(2006). Transportation management. Jakarta, Indoensia: Raja GrafindoPersada.

24. Stompzka.(2010). Sociology of social change. Jakarta, Indonesia: KencanaPrenada Media Group.

25. Sutrisno.(2015). Jabarmetrotv news. Retrieved from http://jabar.metrotvnews.com/read/2015/10/22/44356 5/pengemudi-gojek-dilempar-gelas-hingga-bonyok.

26. Sudarnoto, W. (2015).Conflict and Resolution.Salam: Syar-i Journal of Social and Culture, 2 (1). https://doi.org/10.15408/sjsbs.v2i1.2236

27. Suyanto, B \&Narwoko, J. B. (2007).Sociology introductory \& applied texts. Jakarta: KencanaPrenada Media Group

28. Wahyuni.(2007). Humanity and society. Jakarta, Indonesia: Ganecca Exact.

29. Warpani.(2002). Road traffic and transport management. Bandung, Indonesia: Penerbit ITB.

30. Wijaya.(2016). Legal aspects of the online road transportation business. Jakarta, Indonesia: SinarGrafika Offset.

31. Alamsyah, Andry\& Imam Rachmadiansyah. (2018). Mapping online transportation service quality and multiclass classification problem-solving priorities. In International Conference on Data and Information Science, Bandung, Indonesia. https://doi.org/10.1088/1742-6596/971/1/012021

32. Pratiwi, A. (2017). Social conflicts between online taxi bike drivers and fleet taxi bike drivers in Curug, Bojogsary, Depok City). Jurnal Makna,.2(1), 1-14.

33. Fisher A. J. (2001). Berghof handbook for conflict transformation. Berlin,Germany: Berghof Research Center for Constructive.

34. Mohamed, D. (2016). Fleet taxi vsnonFleet taxi). Retrieved fromhttp://learningcapital.biz/2016/03/bluebird-vsuber-taksi-armada-vs-taksi-tanpa-armada/

35. Kristo, F. Y.(2017). The beginning of online transportation mushrooms in Indonesia. https://inet.detik.com/cyberlife/d-3609781/awal-mulatransportasi-online-menjamur-di-indonesia.

36. Anwar, A. A. (2017). Online vsconventional: Advantages and conflicts among transportation Modes in Makassar city).JurnalEtnografi Indonesia, 2(2),20-246.

37. Rathod, R. V., \&Khot, S. T. (2016). The smart approach to public transport. International Journal of Advanced Engineering, Management and Science. 2(9), 1603-1606.

38. Setyowati, K. \&Rina, H. H. (2017). Conventional vs online transportation: Governance based conflict resolution. In International Conference on Social and Political Sciences (ICoSaPS), Surakarta, Indonesia. https://doi.org/10.5220/0007032900010001.

39. Cetin, T. \&Deakin, E.(2019). Regulation of taxis and the rise of ridesharing. Transport Policy, Elsevier, 76, 149158. https://doi.org/10.1016/j.tranpol.2017.09.002.

40. Wijayanto, I., Sasami, I. B., Nugroho, R. A., \& Suharto, D. G. (2018). Conflict resolution of online transportation vs conventional transportation: A literature review. Advances in Social Science, Education and Humanities Research, 241, 141-152. 